\title{
A new genus and species of Paedembiidae (Embioptera) from Kyzyllkum Desert (Uzbekistan)
}

\author{
Новые род и вид Paedembiidae (Embioptera) из пустыни \\ Кызылкум (Узбекистан)
}

\author{
Alexander G. Blyummer \\ А.Г. БАюммер
}

\begin{abstract}
All-Russian Plant Quarantine Centre, Pogranychnaya St., 32, Bykovo, Moscow Region 140150, Russia. E-mail: agbugs@mail.ru Всероссийский центр карантина растений, ул. Пограничная, д. 32, пос. Быково, Раменский район, Московская область 140150 , Россия.
\end{abstract}

KEY WORDS: Embioptera, Paedembiidae, new genus, new species, Kyzylkum Desert.

КЛЮЧЕВЫЕ СЛОВА: Embioptera, Paedembiidae, новый род, новый вид, пустыня Кызылкум.

ABSTRACT. Uranembia rivkusi gen. et sp.n. (Embioptera: Paedembiidae) is described from the Kyzylkum Desert in Uzbekistan.

РЕЗЮМЕ. Из пустыни Кызылкум в Узбекистане описаны новые род и вид эмбий Uranembia rivkusi gen. et sp.n. (Embioptera: Paedembiidae).

\section{Introduction}

Family Paedembiidae Ross, 2006 consists of two monotypic genera, Paedembia Ross, 2006 from Afghanistan and Badkhyzembia Gorochov et Anisyutkin, 2006 from Turkmenistan [Gorochov, Anisyutkin, 2006; Ross, 2006]. New monotypic genus of this family is found in Uzbekistan and described below. Holotype of a new species is deposited in the Zoological Museum of Moscow State University.

\section{Taxonomy}

Order Embioptera

Family Paedembiidae Ross, 2006

Uranembia Blyummer, gen.n.

Type-species: Uranembia rivkusi Blyummer, sp.n., here designated.

DIAGNOSIS. The new genus differs from two other genera of Paedembiidae by the ratio of the size of the antenna's segments $2-4$, the structure of mesonotum, the number and location of setae and spines of basi- and mesotarsus of the hind legs. In Uranembia the $3^{\text {rd }}$ segment is less than two times longer than the $2^{\text {nd }}$ or $4^{\text {th }}$, while in Pedembia and Badkhyzembia it 3 times longer. In addition, the new genus differs from Paedembia by smaller size of the cerci and from Badkhyzembia by the shape of the hooked process at the base of the basal segment of the male's left cercus. This process detaching from the cercus in Badhyzembia does not form a curve, while in Uranembia it forms a wide one.
DESCRIPTION. Male is large for webspinners, apterous. Body slender, light brown (Fig. 1). In comparison with the body the color of the antennae, mandibular palpi, legs and cerci is in a lighter tone, pale yellow. The head capsule is large, oblong-oval; eyes small, black; antenna is moniliform, with small sparse pubescence segments; includes more, than 20 segments in the holotype, apical segments of both antennae are missing; the $1^{\text {st }}$ and $3^{\text {rd }}$ segments are longer than the others; $3^{\text {rd }}$ segment is less than two times longer than the $2^{\text {nd }}$ or $4^{\text {th }}$ (Fig. 2). The mandibles are elongated, tapering to the upper part; there are 2 basal incisor teeth on the left mandible and single on the right; the apical denticles are larger than the basal. The submentum is rectangular. The pronotum is broad, tapering from the base to the apex; its length greater than the width; mesonotum is narrower and longer than the pronotum; triangular; with deep longitudinal median sulcus; at the distal part becoming gradually very narrow; metanotum almoust quadrate.

The forward pair of legs, like in all embiids, are with swollen apical segments of tarsus. Apical segment of hind tarsus is longer than those of middle one in 1.5 times, while its basitarsi of in 1.5 times less.Papilla on the $2^{\text {nd }}$ segment of hind tarsus is concave. Abdomen elongate; its shape is cylindrical; male's $10^{\text {th }}$ tergite is assimetrical having a large rounded hind lobe. Processes or cleavages structures are missing. Epiproct is oval, semi-membranous, almost connected with the $10^{\text {th }}$ tergite, and located beneath the apical part of the posterior lobe of the tergite. The male^s genital plate $\left(9^{\text {th }}\right.$ sternite) is similar to the apical sternites of the abdomen, with well-developed posterior lobe, fused with coõopodites of the $9^{\text {th }}$ sternite. The posterior lobe of the genital plate is separated from the main part by a distinct crease (Figs 3-4). The male cerci and paraprocts are skewed (Figs 3-4). The paraprocts and right cercus without spurs or protruding structures. The left cercus has a long hooked appendage beginning in the lower part of its base going upward. The sclerites of the thorax and abdomen are covered with fine setae.

ETYMOLOGY. The new genus is named according to the location within the boundaries of the uranium-bearing province in the North-Eastern Kyzylkum. 


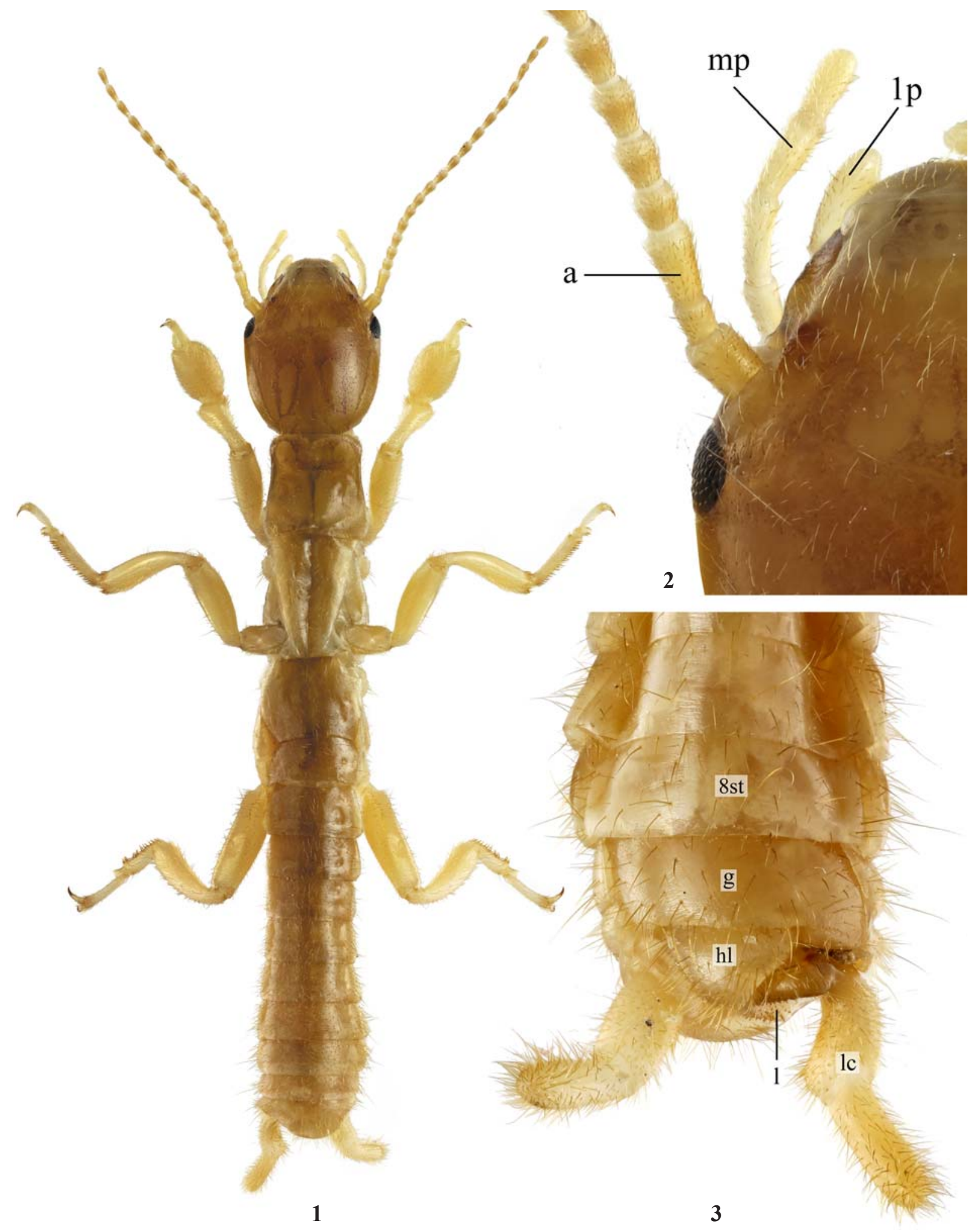

Figs 1-3. Uranembia rivkusi gen.n., sp.n., male. 1 - body, dorsal view; 2 - the distal part of antenna and mouth parts, dorsal view; 3 - the apical part of abdomen, ventral view; a — antenna; $\mathrm{mp}$ - maxillary palps; lp — labial palps; lc — left cercus; $\mathrm{g}$ - genital plate; $\mathrm{hl}$ - posterior lobe of genital plate; 1 - lobe of basal segment of left cercus; $8 \mathrm{st}-8^{\text {th }}$ sternite.

Рис. 1-3. Uranembia rivkusi gen.n., sp.n., самец. 1 - тело сверху; 2 - нижняя часть усика и ротовые придатки; 3 - вершина брюшка, снизу; a — усик; $\mathrm{mp}$ - челюстные щупики; lp — губные щупики; lc — левый церк; $\mathrm{g}$ - генитальная пластинка; $\mathrm{hl}$ — задняя лопасть генитальной пластинки, 1 - лопасть основного сегмента левого церка, $8 \mathrm{st}-8$-й стернит. 


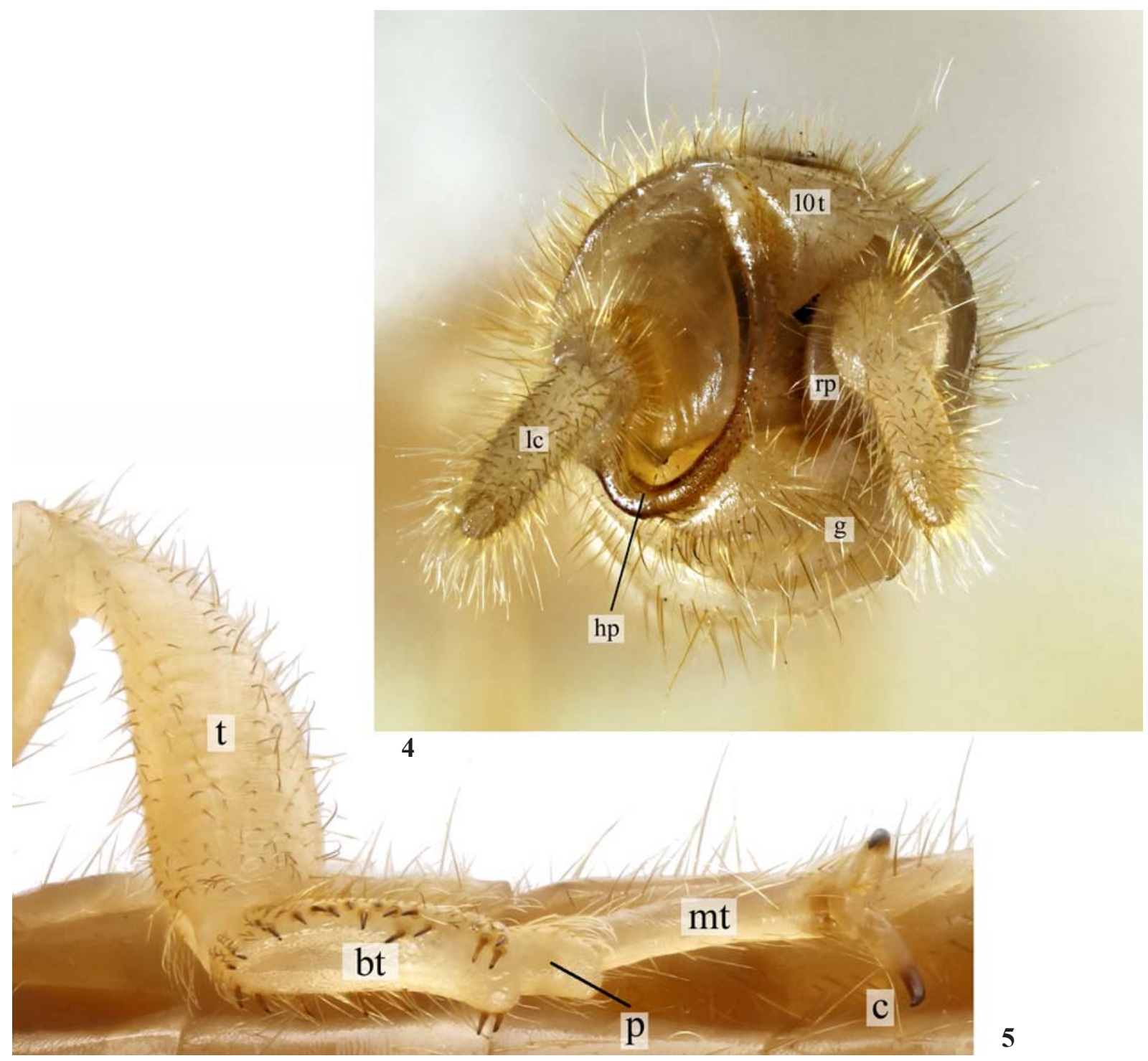

Figs 4-5. Uranembia rivkusi gen.n., sp.n.: 4 - terminal segments of abdomen, rear view; 5- male hind tibia and tarsi; lc - left cercus; $\mathrm{g}$ — genital plate; $\mathrm{hp}$ — hamate process of basal segment of left cercus; $10 \mathrm{t}$ - $10^{\text {th }}$ tergite; $\mathrm{rp}$ — right paraproct; $\mathrm{t}$ — tibia; bt — basitarzus; $\mathrm{mt}$ - metatarzus; $\mathrm{p}$ - papilla of $2^{\text {nd }}$ segment of hind basitarsi; $\mathrm{c}$ - claw.

Pис. 4-5. Uranembia rivkusi gen.n., sp.n.: 4 - вершина брюшка, сзади; 5 - задние голень и лапка самца; lс — левый церк; g генитальная пластинка; hp — крючковатый вырост базального сегмента левого церка; $10 \mathrm{t}$ - 10-й тергит; гр — правый парапрокт; t — голень; bt — базитарзус; $\mathrm{mt}$ - метатарзус; p — папилла 2-го членика задней лапки; с — коготок.

\section{Uranembia rivkusi Blyummer, sp.n. \\ Figs $1-6$}

MATERIAL. Holotype $0^{\top}$, the Republic of Uzbekistan, Navoi region, Tamdy District, $8.5 \mathrm{~km}$ to the North-East of the village Ajakkuduk, North-Eastern part of the Kyzylkum Desert, the north foothill plain of the Sangruntau Mountain Ridge, $41^{\circ} 12^{\prime} \mathrm{N}, 65^{\circ} 17^{\prime} \mathrm{E}$, 1.05.1997, A. Blyummer leg. Preserved in $70^{\circ}$ alcohol and deposited in the Zoological Museum of Moscow State University. Paratype + the same data as in holotype, currently in temporary storage at the laboratory of insect taxonomy of the Zoological Institute RAS, subsequently to be deposited in the Zoological Museum of Moscow State University.

DESCRIPTION. Male (holotype). As described in the generic treatment. Shape of body, head (partly), structure of abdominal apex and hind femora and tarsus as in Figs 1-5.
Measurements (mm). Body length -16.5 , head -3.3 . Pronotum - 1.9, mesonotum - 2.3; fore femora -1.7 , fore tibiae -1.8 , fore metatarsi -1.6 ; middle femora -1.8 , middle tibiae -1.8 , middle tarsus -2.1 ; hind femora 2.1 , hind tibiae -1.7 , hind tarsus -1.9 , cerci -1.8 .

Female (paratype). Similar to male, but mach larger (Fig.6). The antennae consist of 23 segments. Other features as in male except apex of abdomen $10^{\text {th }}$ tergite and shape of cerci that are symmetrical.

Measurements (mm). Body length -31.0 , head - 4.5. Pronotum - 3.8, mesonotum - 4.3; fore metatarsi - 2.1; hind femora -2.8 , hind tibiae -1.8 , hind tarsus -1.8 ; cerci -1.9 .

ETYMOLOGY. The new species is named after Yuri Zalmanovitch Rivkus, the well-known epidemiologist, who has worked over 50 years in the Kyzylkum Desert. 


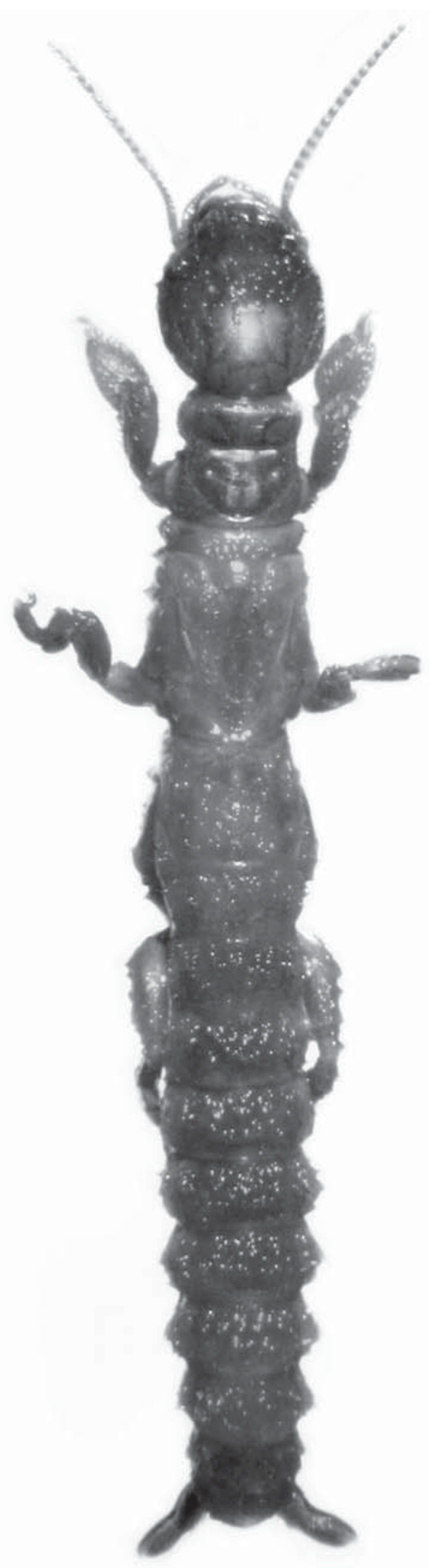

Fig. 6. Uranembia rivkusi gen.n., sp.n., female, dorsal view. Рис. 6. Uranembia rivkusi gen.n., sp.n., самка, вид сверху.
DISCUSSION. The described species demonstrates extreme adaptation to arid conditions. This is evidenced by the coloration of the integument of the imago, dwelling in sandy and loamy landscapes, a solitary lifestyle, active at night and early morning.

Thus, the family Paedembiidae currently includes three genera with three species, Paedembia afghanica Ross, 2006, Badkhyzembia krivokhatskyi Gorochov et Anisyutkin, 2006 and Uranembia rivkusi sp.n., distributed in desert regions of Afghanistan, Turkmenistan and Uzbekistan, respectively.

ACKNOWLEDGEMENTS. The author expresses gratitude to Yu.Z. Rivkus. The detection of new taxon become possible with his help. I wish to thank K.V. Makarov and A.G. Volkov for the assistance in the description of the new taxon, in particular for photographs of the holotypes of male and female, as well as T.A. Blyummer for preparing images for publication.

\section{References}

Gorochov A.V., Anisyutkin L.N. 2006. A new genus and species of Paedembiidae from Turkmenistan // Proceedings of the California Academy of Sciences. Ser.4. Vol.57. No.28. P.795-797.

Ross E.S. 2006. Paedembiidae, a remarkable new family and infraorder of Embiidina from Afghanistan // Proceedings of the California Academy of Sciences. Ser.4. Vol.57. No.27. P.785-794. 